http://journals.ums.ac.id/index.php/ijolae

\title{
"Make A Match Model" for Improving the Understanding of Concepts and Student Learning Results
}

\author{
Ana Juliani $^{1}$, Ali Mustadi ${ }^{2}$, Intan Lisnawati ${ }^{3}$ \\ ${ }^{1,2}$ Department of Elementary School Teacher Education, Universitas Negeri Yogyakarta, In- \\ donesia \\ ${ }^{3}$ Mathematics Department, National Central University, Taiwan
}

DOI: 10.23917/ijolae.v3i1.10269

Received: February $15^{\text {th }}, 2020$. Revised: March $23^{\text {th }}, 2020$. Accepted: March $25^{\text {th }}, 2020$

Available Online: April 20 $0^{\text {th }}, 2020$. Published Regularly: January $1^{\text {st }}, 2021$

\begin{abstract}
This study applies the "Make A Match model" to mathematics subjects, in increasing the ability to understand concepts and student learning outcomes in mathematics. This type of research is Classroom Action Research (CAR) and uses a Kemmis and Taggart model design with four stages, namely 1) Planning, 2) Action, 3) Observation, and 4) Reflection with a qualitative approach. This study uses 3 cycles, namely pre-cycle, cycle I and cycle II. Each cycle consists of four stages, namely: planning, action, observation, and reflection. This research was conducted at Yogyakarta PGRI University. The research subjects are secondsemester students majoring in Elementary education (Pendidikan Guru Sekolah Dasar, hereafter called "PGSD"). The instrument used was a test that contained questions in the form of essays. Analysis of the data used is qualitative descriptive analysis. The results were obtained based on indicators of concept understanding, namely in the second cycle which increased including 1) students who were able to restate the concept from $62.50 \%$ in the pre-cycle to $76.38 \%$ in the second cycle, 2) students who were able to give examples $72.76 \%$ in the pre-cycle to $76.38 \%$ in the second cycle, 3) students who are able to present concepts in various representations from $70.86 \%$ in the pre-cycle to $85.34 \%$ in the second cycle, and 4 ) students who are able to associate internal or external Make A Match model from $70.69 \%$ pre-cycle to $76.38 \%$ in cycle II. It was concluded that the "Make A Match learning model" can improve students' understanding of concepts and learning outcomes in mathematics learning.
\end{abstract}

Keywords: learning results, make a match model, understanding of concepts

Corresponding Author:

Ana Juliani, Department Of Elementary School Teacher Education, Universitas Negeri Yogyakarta, Indonesia E-mail: anajuliani1993@gmail.com

\section{Introduction}

The development of assessment models for students has always been a polemic among academics and practitioners, and further reinforces that assessment in learning is very important. Classification of assessment of learning outcomes according to Bloom's Taxonomy consists of cognitive aspects, attitudes and skills. Therefore, the assessment of learning outcomes must be comprehensive based on these three aspects
(Anderson, 2011). In general, learning outcomes include several aspects, namely cognitive views of the learning process, and affective views of learning outcomes. Hu (2014) says cognitive learning processes are often measured as test scores and assignments, while affective learning outcomes are often measured in terms of attitudes, values, aspirations, personalities and self-concepts. Brooks (2014) concluded in his research that assessment of learning outcomes is expected 
to change the way students learn. Whereas Keshavarz (2011) argues that learning outcomes focus on the cognitive development, behavior and attitudes of students as seen from the way they interact in learning activities.

Locke (Suneetha, Rao \& Rao, 2011) revealed that mathematics is one way for students to solve problems using the power of reasoning. In addition to exercising the power of reasoning, he also develops students' mental abilities in logical thinking, observing, remembering, concentrating, and increasing student confidence (Suneetha, Rao, and Rao, 2011). There are several important things that need to be considered in learning mathematics, namely: 1) teaching about developing student characteristics, 2) involving students in every learning activity in mathematics, 3) changing learning from concrete learning to abstract, and 4) using good communication to encourage student understanding (Reys, 2012). Eurika \& Fritz (2018) argue that mathematics learning must combine empirical findings with curriculum demands.

Another opinion was expressed by Targated News Service (2015), that mathematics is a very important science of curriculum in the world, because it must be able to invite students to be able to think critically and solve problems that are classified as complex and can compete in this 21 st century. While Zipper et al (2017) argue that mathematical skills are very valuable because they are considered professional ;in everyday life mathematics is used to manage finances. Mathematical learning will be more meaningful when learning is dominated by active students while the teacher acts as a facilitator (Smith, 2018). In addition, learning mathematics must also be fun, inspiring, innovative and diverse so that students are easier and more effective in capturing learning (Root- zen, 2015). So by learning mathematics someone has attitudes and habits of critical, logical, and systematic thinking. Understanding concepts is the key to learning. Understanding this concept emphasizes that every material taught to students is not only memorized, but also for practice that students will do. If students do not have a good understanding of concepts, students lack understanding of material concepts in mathematics, so students cannot solve mathematical problems correctly. A teacher's understanding of how a student can learn mathematics is an important element to start understanding misconceptions in mathematics (Hansen, 2011). Li \& Ni (2013) said that understanding the relationship of mathematics with everyday life can be a new challenge for lecturers in learning.

Satrio (2016) in his research revealed the low achievement, understanding of concepts and student learning outcomes due to several factors, including the use of mathematical learning models that are considered ineffective for students, the lack of student focus in learning so that when lecturers provide opportunities to ask questions about material that is not yet understood, no one dared to ask questions because they did not understand what was explained by the lecturer, and gave examples of questions and practice questions to students. The learning model makes students only as static objects that must obey all instructions from the lecturer, thus making students passive in participating in learning.

An important role in conceptual understanding of mathematics learning is to balance factual knowledge with procedural abilities, so students can become active and effective learners (Six Principles for School Mathematics, 2014). The instruction process for students both with and without disabilities, lecturers need a diagnostic process to assess 
students' level of understanding of Make A Match Model (Hunt \& Little, 2014). Instruction is a process that can help students to achieve learning targets (Nitko \& Brookhart, 2011). In Bloom's Taxonomy, understanding is the ability to absorb the meaning of a subject, where a student will be declared to understand the material if it can construct the meaning of the message received both orally and in writing (Anderson \& Krathwohl, 2010).

The results of preliminary observations made on PGSD students found that elementary school mathematics learning outcomes are still low. In addition, there were several problems found, including students who were busy talking about unrelated learning materials, student activities related to learning were still low because students listened more to the material from lecturers, students were less responsive when lecturers were having difficulties. turn on the LCD to use it to convey the material, the learning methods used do not vary, some even sleep when the lecturer explains the material. If this is not handled immediately, it will greatly affect the student's final grade.

Several other problems are identified as factors that cause low student learning outcomes: First is learning that is dominated by lectures or presentations by lecturers and students record what is explained by the lecturer, then lecturers hold the Mid Semester Exams and Final Semester Exams. With such learning students are not given the opportunity to hone their abilities or knowledge. So learning motivation is reduced and interest in learning basic mathematics decreases.

Second, the lecturer does not arrange the environment and learning atmosphere. The learning environment and atmosphere still looks conventional and monotonous. The learning table arrangement still uses the old pattern, where the learning table is arranged in one line so students sit sideways and extend backwards. By setting this learning environment and atmosphere, it causes absorption and understanding of students' concepts to differ between those who sit in the front and those who sit in the back. Third, lecturers pay less attention to the different characteristics of each student. For this reason, it is important to make improvements in the learning process through the application of creative and innovative cooperative learning models. Thus, students become interested in learning basic mathematics.

According to Arends \& Kilcher (2010) cooperative learning is a learning strategy carried out in groups to maximize active students in learning, active in interacting and active in working together. This is confirmed by Pederson \& Digby (2013) which states that cooperative learning can be used at the educational level in each subject. This opinion is commensurate with the research results of Thruston, Karagiannidou, Tolmie, Christie, Murray, Topping (2010) who said that cooperative learning can be applied at all levels of education and can improve student learning outcomes.

One model of cooperative learning that can be applied in mathematics learning is A Match learning model. Rusman (2012) explains that the Match Model is a model that can be used for all subjects and for all age levels of students, and in this method students look for pairs of cards while learning about concepts or topics in a pleasant atmosphere. Agus Suprijono (2012) suggests that the things that need to be prepared if learning is applied with the Match model are cards. Cards consist of cards that contain questions and other cards that contain answers to these questions. So, according to researchers through the application of the Match type of cooperative learning model, it will be more helpful for students to understand mathema- 
tical concepts and can also improve learning outcomes.

Based on the description above, the purpose of this study is to apply the Match learning model, to improve understanding of concepts and student learning outcomes in mathematics. This study also aims to determine the contribution of the Match learning model to the understanding of concepts and student learning outcomes.

\section{Method}

This research was conducted at Yogyakarta PGRI University. This type of research is Classroom Action Research. Suharsimi Arikunto (2010) said briefly that Classroom Action Research is a learning activity that consists of actions that are raised and carried out simultaneously in the classroom. The research subjects were 29 students in class A7, with the composition of 18 female students and 11 male students.. The data analysis technique used in this study uses quantitative analysis and uses descriptive statistics. In this study, data collection techniques used for research are through tests that contain a series of questions.The test given is adjusted to the specific learning objectives to be achieved, then adjusted to the mathematics material of
A7 grade students of Yogyakarta PGRI University and by using the Make A Match learning model given by the lecturer. The ability to understand concepts and student mathematics learning outcomes through the application of Make A Match learning models can be said to be complete if they meet the completeness criteria. To calculate the percentage of students' understanding of concept achievement, a formula is used:

$$
\mathrm{K}=\frac{\Sigma k_{m}}{m} \times 100 \%
$$

Information:

$\mathrm{K}$ : percentage of achievement indicator of understanding concepts and learning outcomes.

$\Sigma k_{m}$ : the number of scores achieved on the indicator of understanding concepts and learning outcomes

$m \quad:$ the total score of the indicator multiplied by the number of students

This Classroom Action Research is divided into 2 cycles and each cycle consists of 2 meetings. The steps of conducting this research through four stages, namely: planning, action, observation, and reflection (Arikunto, 2010: 137). The flowchart used in this research can be described:

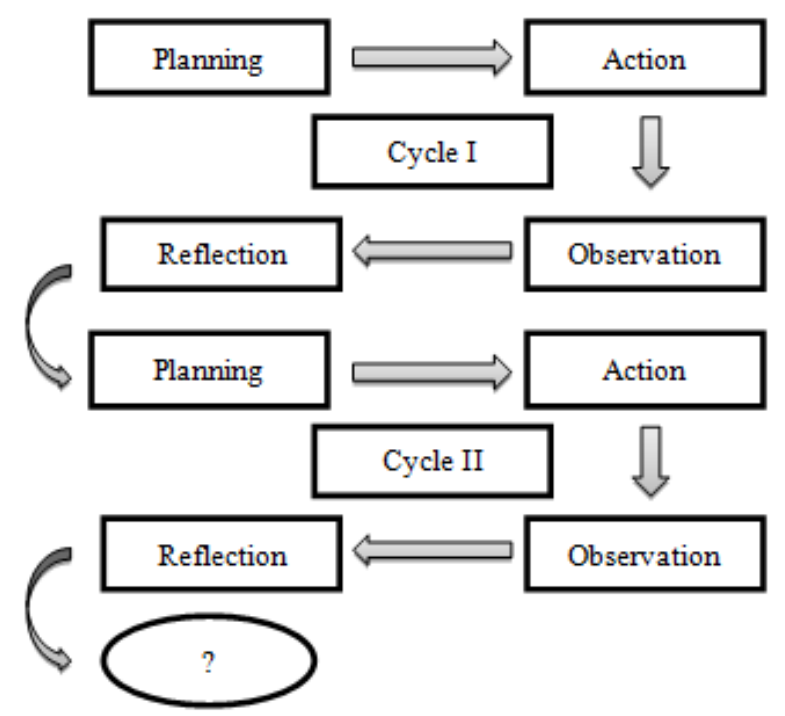

Figure 1. Class Action Research Model according to Kemmis \& M. Taggart (Arikunto, 2008:16) 


\section{Result and Discussion}

Learning that has been done thoroughly in the action cycle I and cycle II through the application of the Making A Match learning model, shows an increase in understanding of concepts and learning outcomes in mathematics in accordance with the indicators that have been used by researchers. Cycle I was conducted in 1 meeting, namely on March 28, 2018, with an allocation of meeting time $2 \times 50$ minutes at 12:30 - 14.50. In this first cycle, the material taught is about multiplication and division numbers. Cycle 1 consisted of 4 stages, namely the planning stage, the action stage, the observation stage, and the reflection stage. In the first stage, namely the planning stage, the researcher designed the learning tools and instruments and discussed these tools and instruments with the elementary mathematics lecturer in the Elementary education (PGSD) study program Yogyakarta PGRI. The next stage is the action stage using the Making a Match model. From the results obtained during the study, the learning process provided by the lecturer was in accordance with the planning of the learning tools that had been prepared together with the researcher.

The learning steps that have been planned in the study use the "Make A Match learning model", in which the lecturer opens the lesson and absences the student, makes an agreement with the student about the learning model that will be used later- the "Make A Match model", arranges the classroom layout into the letter $U$ to make it easier for students do a game with the model of Making a Match, then the lecturer gives apperception and learning objectives to students while showing 2 types of cards namely question cards and answer cards. After the lecturer gives the apperception and learning objectives the lecturer explains the material about Multiplication number and Distributi- on number for 30 minutes. When explaining the material, there were still some students who did not focus on learning, such as cool chatting alone, and sleeping in the classroom. Then the lecturer gives the opportunity for students to ask questions related to the material that has been delivered that they do not understand. After explaining the material, the lecturer held a demonstration by asking all students to make two large groups, the group formed in a long line in the middle of the room and facing each other between group A and group B. Then the lecturer took the question card and answer card and explained it to students about how to play. After the lecturer explains the rules of the game, the lecturer distributes question card to group A and answer card to group B, and invites students to immediately look for the pair of cards held without giving students the opportunity to think which pair of cards they have. After students get the pair of cards, students immediately report to the lecturer and immediately sit in pairs. From this game, the lecturer noted that only 15 pairs of students managed to find their partners and 14 students who did not find their partners. For students who have succeeded in collecting points, the lecturer gives an award, as well as motivation for students who have not yet managed to find a card partner and who do not get points. This demonstration is carried out for 20 minutes. Then the lecturer closes the lesson by praying and saying hello.

Student learning outcomes in basic mathematics subjects is the level of understanding of student concepts that can be mastered by students on the material that has been delivered by the lecturer, namely cognitive abilities, affective abilities, and psychomotor abilities. The learning outcomes and understanding of this concept can be shown as follows: 
Table 1. Data about increasing the understanding of concepts and mathematics learning outcomes of UPY PGSD students

\begin{tabular}{|c|c|c|c|c|}
\hline \multirow{2}{*}{ No } & \multirow{2}{*}{ Aspect } & \multirow{2}{*}{$\begin{array}{c}\text { Before } \\
\text { Research }\end{array}$} & \multicolumn{2}{|c|}{ After research } \\
\hline & & & Cycle I & Cycle II \\
\hline 1 & Restate the concept and learning outcomes & $62.5 \%$ & $67.5 \%$ & $76.03 \%$ \\
\hline 2 & Give an example & $72.76 \%$ & $74.14 \%$ & $76.38 \%$ \\
\hline 3 & Presenting the concept of & $70.86 \%$ & $75.17 \%$ & $85.34 \%$ \\
\hline 4 & Connecting concepts with everyday life & $70.69 \%$ & $74.66 \%$ & $76.38 \%$ \\
\hline
\end{tabular}

Table 1 shows the comparison of student learning outcomes before conducting research and after conducting research. The results obtained are not too high but have in- creased in each cycle. The following data improve the understanding of concepts and student learning outcomes before and after research in graphical form:

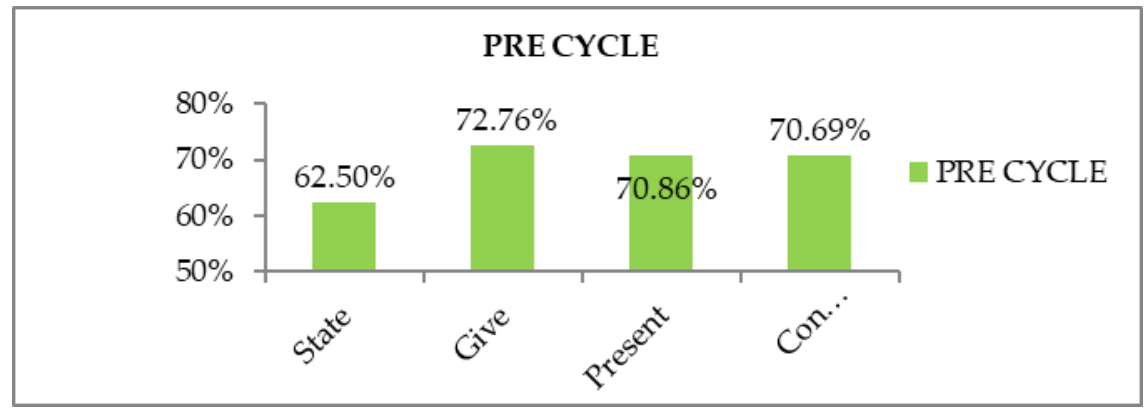

Figure 2. Pre cycle understanding results the concepts and learning outcomes of UPY PGSD students

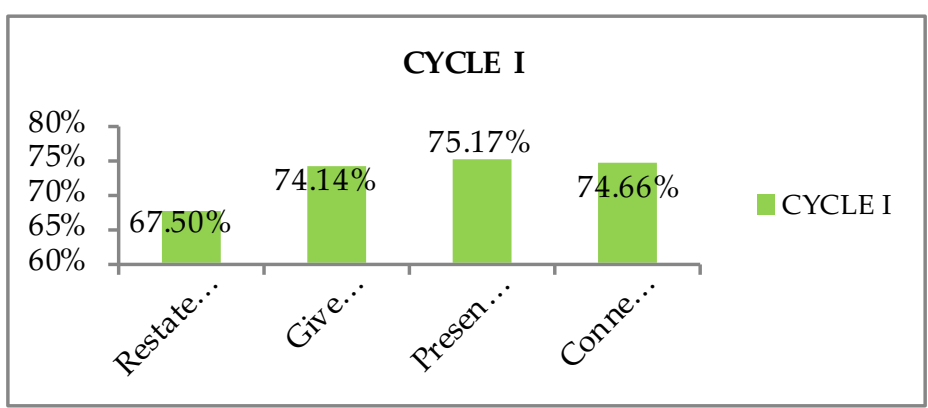

Figure 3. The results of the first cycle of understanding the concepts and learning outcomes of UPY PGSD students 


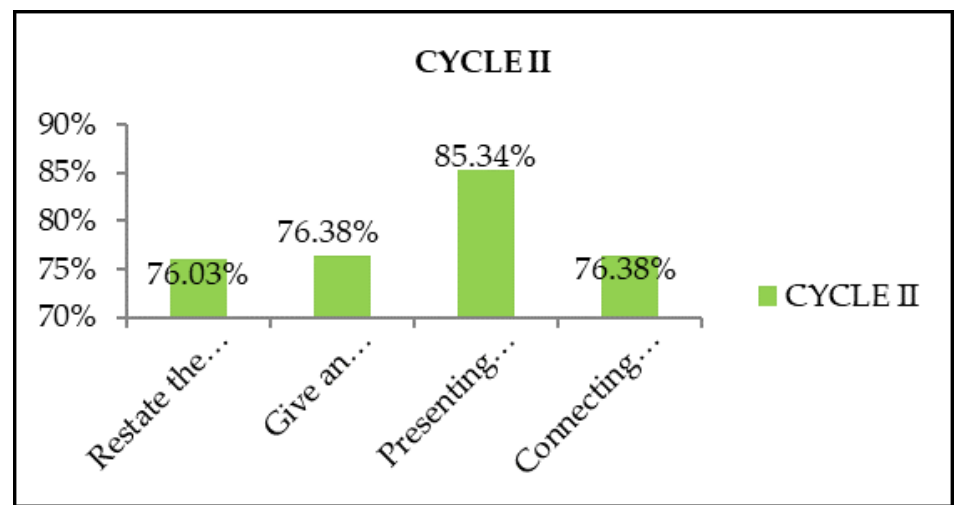

Figure 4. The results of the second cycle of understanding the concepts and learning outcomes of UPY PGSD students

Research conducted by researchers on understanding concepts and student learning outcomes in mathematics has increased from before the implementation of the action to the first cycle and the second cycle of action by applying the "Make A Match learning model". This can be shown from the indicators, namely 1) students who are able to restate the concept from $62.50 \%$ to $76.38 \%, 2$ ) students who are able to give examples from $72.76 \%$ to $76.38 \%, 3)$ students are able to present concepts in various representations from $70.86 \%$ to $85.34 \%$, and 4 ) students who are able to connect mathematical concepts internally or externally from $70.69 \%$ to $76.38 \%$.

Overall the model of "Make A Match learning" can improve the understanding of concepts and student learning outcomes in mathematics from cycle I to cycle II. Increased understanding of students' mathematical concepts can clearly be seen in cycle II. The learning process in the second cycle shows students' attitudes that can be controlled through learning activities provided by the lecturer. This condition has an impact on increasing understanding of mathematical concepts in restating concepts, giving examples, presenting concepts, and linking mathematical concepts internally or externally.

Based on the results of discussions between lecturers and researchers, the use of
"Make A Match Model" can be used as an alternative in improving the understanding of concepts and mathematics learning outcomes of PGSD students. This research was conducted by applying two learning cycles with the same learning model as that Make A Match.

The results of the study through the test, pre-cycle activities 29 students on the first indicator can be seen that students' understanding of Make A Match model is still very low with an average of $62.5 \%$ or equivalent to 11 students who completed 29 students, then in the first cycle increased to $67.5 \%$ but in this cycle 1 the number of students who finished was still the same as the pre-cycle which was 11 students who completed from 29 students because in the first cycle there was no increase, so research in cycle II, in this cycle student's understanding of Make A Match model had increased to $76.03 \%$, with 24 students completed from 29 students. So the increase in understanding of concepts and learning outcomes of UPY PGSD students between cycle I to cycle II was $8.53 \%$.

Then the results of research through tests on concept of understanding and learning outcomes, in pre-cycle activities of 29 students on the second indicator can be seen that the understanding of concepts and student learning outcomes in mathematics is quite good with an average of $72.76 \%$ or equivalent to 22 students who have comple- 
ted from 29 students, then in the first cycle increased to $74.14 \%$ ie as many as 25 students who completed from 29 students, then in the second cycle the understanding of concepts and learning outcomes of students increased to $85.34 \%$ ie as many as 27 students who completed from 29 students. So the increase in understanding of concepts and learning outcomes of UPY PGSD students between cycle I to cycle II was $11.2 \%$.

Then in the third indicator in the precycle activities, it is known that the average understanding of Make A Match model of students is $70.86 \%$ or as many as 13 students who finished out of 29 students because in the pre-cycle activities the number of students completing is still small; the researchers take action by applying cycle I. In the first cycle the results obtained an average understanding of concepts and learning outcomes of $75.17 \%$ or as many as 22 students who completed. It can be seen from the precycle activities to cycle I experienced a significant increase, but researchers are still trying to continue the cycle to cycle II. After the second cycle is applied, the average results of understanding concepts and mathematics learning outcomes of students are obtained by $85.34 \%$ or as many as 26 students who complete. So it can be concluded on this third indicator that students have begun to understand mathematical concepts given by the lecturer. So the increase in understanding of concepts and learning outcomes of UPY PGSD students between cycle I to cycle II on this third indicator is $10.17 \%$.

Finally, in the indicator four, the precycle results obtained the average understanding of Make A Match model is $70.69 \%$ or 17 students who completed from 29 students. Because in the pre-cycle activities the number of students who completed was still relatively small, the researchers took action by applying the first cycle. In the first cycle, the average understanding of the concept was $74.66 \%$ or 23 students who completed it. From pre-cycle activities to cycle I can be seen that the average understanding of the concept of students has increased significantly, but researchers are still trying to continue the cycle to cycle II. After the second cycle is applied, the average result of understanding Make A Match model is obtained by $76.38 \%$ or as many as 24 students who complete it. Then it can be concluded on this fourth indicator, students have begun to understand Make A Match model given by the lecturer. So the increase in understanding of the concept of UPY PGSD students between cycle I to cycle II on this fourth indicator is $1.72 \%$.

From the results of the tests carried out from cycle I to cycle II, the researcher can conclude that the application of the "Make a match learning model" has been proven to be able to improve the understanding of concepts and learning outcomes of UPY PGSD students. These results can be proven by the average and the number of students who complete each cycle on each indicator.

\section{Conclusion}

Based on the results of the above research conducted on A7 grade PGSD students it can be concluded that 1) "Make a Match" is a learning model designed to help students learn and understand the material, and help improve student learning outcomes, 2) the "Make a Match model" can be used in mathematics learning and greatly helps improve student learning outcomes, and 3) based on the test instrument used there is an increase in understanding of concepts and student learning outcomes. 


\section{References}

Agus, Suprijono. 2012. Cooperative Learning: Teori dan Aplikasi Paikem. Yogyakrta: Pustaka Pelajar.

Anderson, Lorin W. \& David Krathwohl. (2010). Kerangka landasan untuk pembelajaran pengajaran dan asessmen. (Terjemahan Agung Prihantoro). New York: Company, Inc. (Buku asli diterbitkan tahun 1956).

Anderson, L. W. \& Krathwohl, D. R. (2011). Taxonomy learning, teaching, and assessing. New York: Longman.

Arends, R. I., \& Kilcher, A. (2010). Teaching for student learning: becoming an accomplished teacher. New York: Routledge.

Brooks, Sara. Et al. (2014). Learning about learning outcomes: the student perspective. Routladge, Taylor \& Francis Group. Vol. 19, No. 6, Hal. 721-733.

Eurika Jansen, V. V., Herzog, M., \& Fritz, A. (2018). Meerkat maths - a comprehensive maths learning programme for grade-R. South african journal of childhood education (SAJCE), 8(2).

Hansen, A. (2011), Childrens errors in mathematics. Exeter, California: SAGE Publication Inc.

Hunt, J. H., \& Little, M. E. (2014). Intensifying interventions for students by identifying and remediating conceptual understandings in mathematics. Council for Exceptional Children.

$\mathrm{Hu}, \mathrm{Z}$. (2014). Students' experience and perceived learning outcomes in international collaborative programs in shanghai, china (Disertasi doctor, University of the pacific stockton, 2014). UMI Dissertation Publishing.

Keshavarz, M. (2011). Measuring course learning outcomes. Journal of learning design, 4, 1-9.

Li, Qi., \& Ni, Y. (2013). Debates in the basic education curriculum reform and teachers' challenges in china. Chinese education \& society, 45(4), 9-21.

Nitko, A. J., \& Brookhart, S. M. (2011). Educational assessment of student. Boston. Pearson/ Allyn \& Bacon.
Pederson, J. E. \& Digby, A. (2013). Secondary school and cooperative learning: theory, models, and strategies. New York: Routledge.

Reys, R., et al. (2012). Helping Children Learn Mathematics. Hoboken: John Willey \& Son, Inc.

Rootzen, H. (2015). Individualized learning through non-linear use of learning objects: with examples from math and stat. Kidmore End: Academic Conferences International Limited.

Rusman, 2012. Model-model Pembelajaran: Mengembangkan Profesionalisme Guru, RajaGrafindo Persada, Jakarta.

Satrio, S. W., \& Vahlia, I. (2016). Efektifitas penggunaan metode pembelajaran quantum learning terhadap kemampuan pemahaman konsep matematis mahasiswa. Jurnal Pendidikan Matematika, 7(2), 275-276.

Six Principles for School Mathematics. (2014). National council of teachers of mathematics, 1-6.

Smith, T. (2018). Active learning in the math classroom. Teach \& learning, 38(7), 2628

Suharsimi, Arikunto. (2010). Dasar-Dasar Evaluasi Pendidikan. Jakarta: Bumi Aksara.

Suneetha, E., Rao, R. S., \& Rao, D. B. (2011). Methods of teaching mathematics. New Delhi: Discovery Publishing House.

Targated News Service (2015). Allabama teacher recognized for enhancing student learning in math and science. Washington, D.C.

Thruston, A., Karagiannidou, E., Tolmie, A., Christie, D., Murray, P., Topping, K. (2010). Enhancing outcomes in school science for pupils during transition from elementary school using cooperative learning. Middle grades research journal, 5, 19-32.

Zipper, E. L., Diamant-Cohen, B., \& Goldsmith, A. Y. (2017). Math counts too!: promoting family engagement in math activities at home. Children \& libraries, 15(2), 38-40. 